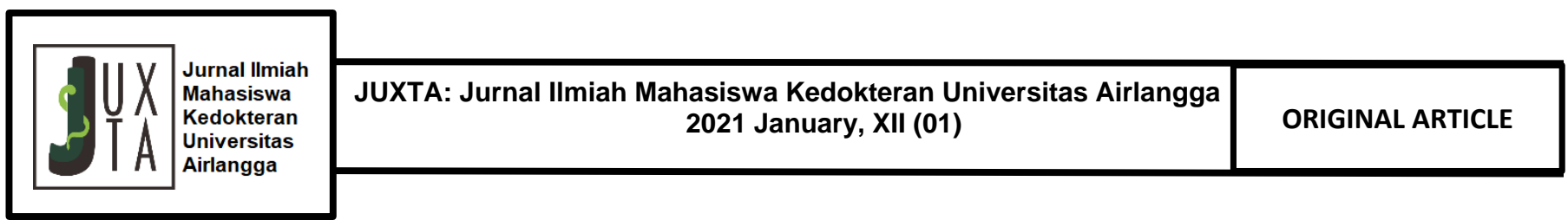

\title{
Maternal Educational Status as One of the Risk Factors Affecting the Incidence of Infants with Low Birth Weight in Dr. M. Soewandhie General Hospital Surabaya
}

\author{
Jihanifa Hega Salsabiila ${ }^{1}$, Hermanto Tri Joewono ${ }^{2}$, Sulistiawati ${ }^{3}$
}

\begin{abstract}
${ }^{1}$ Faculty of Medicine, Universitas Airlangga, Surabaya, Indonesia.
${ }^{2}$ Department of Obstetrics and Gynecology, Faculty of Medicine, Universitas Airlangga/Dr. Soetomo General Hospital, Surabaya, Indonesia.

${ }^{3}$ Department of Public Health and Preventive Medicine, Universitas Airlangga, Surabaya, Indonesia.
\end{abstract}

A B S T R A C T

Introduction: Infants with low birth weight (LBW) was one of the main indicators of the cause of high infant mortality rates (IMR). The causes of IMR and maternal mortality rate (MMR) were determined by factors in maternal condition before and during pregnancy. In 2015, LBW in Surabaya reached $2.58 \%$, namely a number of 1,261 of 48,783 born babies weighed. This study was performed by analyzing the effect of educational status as a risk factor affecting LBW in Dr. M. Soewandhie General Hospital Surabaya.

Methods: This study used case control method with a retrospective approach using patient medical records as secondary data. The sample population were mothers who gave birth to infants with birth weight of $1,500-4,000 \mathrm{~g}$ in Dr. M. Soewandhie General Hospital Surabaya. The number of samples consisted of 80 patients with case and control ratio of $1: 1$. The sampling technique used was purposive sampling. Data collection techniques used variable data collection sheets taken from secondary data, namely medical records. Data analysis was performed by ChiSquare and Odds Ratio (OR) statistical tests.

Results: Based on Chi-Square test, there was a relationship between educational status ( $p=0.034$ ) with the incidence of LBW. The results of this study indicated that the educational status of mothers that graduated from elementary school - senior high school was at risk of 9,750 times in delivering LBW.

Conclusion: Educational status was the risk factor that had a correlation with LBW.

* Correspondence: hermanto.tri@fk.unair.ac.id

JUXTA: Jurnal IImiah Mahasiswa Kedokteran Universitas Airlangga

p-ISSN: 1907-3623; e-ISSN: 2684-9453

DOI: $10.20473 /$ juxta.V12I12021.10-13

Open access under Creative Commons Attribution-ShareAlike 4.0 International License

(CC-BY-SA)
ARTICLE INFO

Article history:

Received 9 November 2020

Received in revised form 26

November 2020

Accepted 8 December 2020

\section{Keywords:}

Low birth weight,

Maternal educational status,

Risk factor. 


\section{Introduction}

Health development in the period of 2015-2019 was included in Healthy Indonesia Program with the aim of improving the health status and nutritional status of the community through efforts by health and community empowerment supported by financial protection and health services. ${ }^{1}$ One of the main objectives of National Medium Term Development Plan (RPJMN) for 2015-2019 was to improve public health status with several indicators of success such as decreasing maternal mortality rate (MMR), infant mortality rate (IMR), and the percentage of low birth weight (LBW). ${ }^{2}$ These three things are related to each other in terms of cause and effect. LBW is a new born weighed in the first hour after birth less than $2,500 \mathrm{~g} \cdot{ }^{3} \mathrm{LBW}$ is one of the main indicators of the cause of high IMR. The causes of IMR and MMR are determined by factors of the mother's condition before and during pregnancy.

In the last 5 years, neonatal mortality rate (NMR) has remained the same at $19 / 1000$ births, while for post neonatal mortality rate (PNMR), there has been a decline from $15 / 1,000$ to $13 / 1,000$ live births. The mortality rate of children under five years old has also dropped from $44 / 1,000$ to $40 / 1,000$ live births. The cause of death in the perinatal group was caused by intra uterine fetal death (IUFD) of $29.5 \%$ and LBW as much as $11.2 \%$. It means that the mother's condition before and during pregnancy greatly determines the condition of the infant. ${ }^{1}$

Based on the results of 2013 Basic Health Research, the percentage of LBW cases in 33 provinces in Indonesia ranged from $7.2-16.8 \%$, with the highest percentage was in Central Sulawesi at $16.8 \%$ and the lowest was in North Sumatra at $7.2 \%$. East Java was ranked 11 th out of 33 provinces in Indonesia. ${ }^{4}$ Based on the data from East Java Provincial Health Office, in 2014, LBW in East Java amounted to $3.35 \%$, amounting to 20,290 out of 606,306 birth infants weighed. ${ }^{5}$ While the data from the Surabaya City Health Office, in 2015 LBW in Surabaya was $2.58 \%$, namely 1,261 out of 48,783 birth infants weighed. ${ }^{6}$

LBW is the main factor that causes miscarriages, stillbirth, birth defects, and low ability of children in the learning process. Meanwhile infants with more weight at birth in the future can be a major factor that affects the health of infants such as obesity, high blood pressure, and heart disease. ${ }^{7}$

Some studies show that premature infants have a high risk of cognitive impairment and congenital defects. Fulfilment of nutritional status both before and during pregnancy by pregnant women is one of the factors that determine the development, growth, and function of the fetal brain. ${ }^{8}$

Risk factors that affect LBW include maternal age, nutritional status, height, parity, multiple pregnancies, smoking habits, alcohol consumption and drugs, drug history (malaria, HIV, syphilis, etc.), pregnancy complications, and status economy (WHO, 2004). Based on the results of the study conducted by Alya at Banda Aceh Maternal and Child Hospital, it was shown that several risk factors affecting LBW were maternal age and multiple pregnancies. ${ }^{9}$ The results of other studies conducted by Sulistian in all South Tangerang health centers showed that several risk factors that affect LBW were maternal height $<145 \mathrm{~cm}$, gestational age $<37$ weeks, mothers who experienced chronic energy deficiency (CED), and anemia. ${ }^{10}$ The results of other studies conducted by Mahayana, et al. at Dr. M. Djamil General Hospital Padang showed that several risk factors that affect LBW were male fetus, low socioeconomic status, mothers who experienced anemia, placental abnormalities, and parity. ${ }^{11}$ Meanwhile the results of other studies conducted by Suwarni, et al. in several Lampung health centers showed that several risk factors that influence LBW were upper arm circumference (UAC), hemoglobin level, and maternal age. ${ }^{12}$

Based on the obtained information, this study aimed to analyze the influence of educational status as one of the risk factors that affect LBW. In accordance with the aim of the study, the title of this study is "Maternal Educational Status as One of the Risk Factors Affecting the incidence of Infants with Low Birth Weight in Dr. M. Soewandhie Surabaya General Hospital".

\section{Methods}

This was a data analysis study that studied the risk factors of LBW infants with a case control method, namely a study that compares case groups with control groups based on exposure status. This study used a retrospective approach using the patient's medical record as secondary data. The population in this study were data obtained from medical records of patients who gave birth to infants with LBW and normal birth weight at Dr. M. Soewandhie General Hospital Surabaya. The inclusion criteria were cases of live births weighed between 1,500-2,499 $\mathrm{g}$ and mothers with complete medical record data, while the exclusion criteria for cases were infants who died. The control inclusion criteria were live-born infants weighed between 2,500-4,000 $\mathrm{g}$ and mothers with complete medical record data, while the control exclusion criteria were infants who experienced death. The number of samples taken according to the sample calculation formula was 33,986 , thus the number of samples was 40 samples. This study used a comparison of case and control groups of 1:1, therefore the total number of samples was 80 samples. In this study, the sampling technique used was purposive sampling.

The dependent variable was an infant weighed 1,500$4,000 \mathrm{~g}$. The independent variable was one of the risk factors that affects the incidence of LBW infants, namely educational status. Data collection techniques in this study used a variable data collection sheet taken from secondary data, namely medical records of patients in Dr. M. Soewandhie General Hospital Surabaya. Data analysis was performed by Chi-Square statistical test and Odds Ratio (OR). 


\section{Results}

The characteristics of research subjects in the case group and the control group based on educational status are explained as follows:

Table 1. Overview of characteristics of research subjects in case groups and control groups based on educational status.

\begin{tabular}{|c|c|c|c|c|c|c|c|}
\hline \multirow{3}{*}{ No. } & \multirow{3}{*}{ Educational Status } & \multicolumn{4}{|c|}{ Group } & \multirow{2}{*}{\multicolumn{2}{|c|}{ Total }} \\
\hline & & \multicolumn{2}{|c|}{ Case } & \multicolumn{2}{|c|}{ Control } & & \\
\hline & & $\mathbf{n}$ & $\%$ & $\mathbf{n}$ & $\%$ & $\mathbf{N}$ & $\%$ \\
\hline 1. & Elementary School & 7 & 17.5 & 7 & 17.5 & 14 & 17.5 \\
\hline 2. & Junior High School & 14 & 35 & 9 & 22.5 & 23 & 28.75 \\
\hline 3. & Senior High School & 18 & 45 & 16 & 40 & 34 & 42.5 \\
\hline 4. & Diploma & 1 & 2.5 & 4 & 10 & 5 & 6.25 \\
\hline 5. & Bachelor & 0 & 0 & 4 & 10 & 4 & 5 \\
\hline & Sum & 40 & 100 & 40 & 100 & 80 & 100 \\
\hline
\end{tabular}

Source: research data, processed

${ }^{\star}$ Comparison between groups

Table 2. Relationship between the incidence of infants with low birth weight and maternal educational status.

\begin{tabular}{|c|c|c|c|c|c|c|c|c|}
\hline \multirow{3}{*}{ Educational Status } & \multicolumn{4}{|c|}{ Group } & \multirow{2}{*}{\multicolumn{2}{|c|}{ Total }} & \multirow{3}{*}{ p (sig) } & \multirow{3}{*}{$\begin{array}{c}\text { Odds Ratio } \\
\text { (95\% Cl) }\end{array}$} \\
\hline & \multicolumn{2}{|c|}{ Case } & \multicolumn{2}{|c|}{ Control } & & & & \\
\hline & $\mathbf{n}$ & $\%$ & $\mathbf{n}$ & $\%$ & $\mathbf{N}$ & $\%$ & & \\
\hline $\begin{array}{l}\text { Elementary School - Senior High } \\
\text { School }\end{array}$ & 39 & 97.5 & 32 & 80 & 71 & 88.8 & & \\
\hline Diploma - Bachelor & 1 & 2.5 & 8 & 20 & 9 & 11.3 & 0.029 & 9.750 \\
\hline Sum & 40 & 100 & 40 & 100 & 80 & 100 & & \\
\hline
\end{tabular}

Source: Research Data, Processed

${ }^{*}$ Comparison between groups

Based on Table 1, it can be seen that most of the characteristics of maternal educational status during pregnancy at the high school level were 34 respondents with a percentage of $42.5 \%$. In the case group, the characteristics of maternal educational status during pregnancy were mostly at the senior high school level with 18 respondents with a percentage of $45 \%$. In the control group, the characteristics of maternal educational status at most were at the high school level with 16 respondents with a percentage of $40 \%$, while at least at the levels of diploma and bachelor each with 4 respondents with a percentage of $10 \%$.

Based on Table 2, it can be seen that in the case group with the variable of maternal educational status during pregnancy there were mothers who had elementary school - senior high school education levels as many as 39 respondents with a percentage of $97.5 \%$, and mothers who had diploma - bachelor education level as much as 1 respondent with a percentage at $2.5 \%$. In the control group with the variable of maternal educational status during pregnancy there were mothers who had an elementary school - senior high school education level of 32 respondents with a percentage of $80 \%$, and mothers who had diploma - bachelor education level as many as 8 respondents with a percentage of $20 \%$. These results illustrated that mothers during pregnancy who had elementary school - senior high school education level was more prevalent in the case group $(97.5 \%)$ compared to the control group (80\%).

The $p$ value (sig) obtained from Fisher Exact Test was 0.029 . These results stated that $p(\mathrm{sig})<0.05$, thus it can be concluded statistically there was a significant influence between the risk of elementary school - senior high school educational status during pregnancy with the incidence of
LBW in Dr. M. Soewandhie General Hospital Surabaya. OR values indicated that pregnant women who had educational status of elementary school - senior high school level had a 9,750 times greater chance of giving birth to infants with LBW compared to diploma - bachelor level of educational status.

\section{Discussion}

Based on Table 1, in the case group with variables of maternal educational status during pregnancy there were mothers who had elementary school - senior high school education levels as many as 39 respondents, and mothers who had diploma - bachelor education level as many as 1 respondent. In the control group with the variable of maternal educational status during pregnancy there were mothers who had an elementary school - senior high school education level as many as 32 respondents, and mothers who had diploma - bachelor education level as many as 8 respondents. Based on the results of the study, the value of $p$ (sig) of 0.029 stated that statistically there was a significant influence between the risk of elementary school - senior high school educational status during pregnancy with the incidence of LBW in Dr. M. Soewandhie General Hospital Surabaya. OR of 9,750 indicated that pregnant women who had educational status of elementary school - senior high school level had a 9,750 times greater 
chance of giving birth to infants with LBW compared to diploma - bachelor level of educational status.

The results of this study are in line with the study conducted by Kumalasari, et al. (2018) which stated that pregnant women who had a low educational status had an opportunity 1,870 times greater in giving birth to infants with LBW compared to pregnant women who had a high level educational status. ${ }^{13}$ The results of this study are also in line with the study conducted by Ekaningrum (2018) which stated that pregnant women who had low level education had a 1,464 times greater chance of giving birth to infants with LBW compared to pregnant women who had high educational status. ${ }^{14}$

Silva, et al. stated that maternal educational status is an appropriate variable for measuring inequality in health care and for assessing pregnancy outcomes. ${ }^{15}$ The higher the maternal educational level, the more mothers get information about LBW, thus the mothers will have more knowledge to prevent the occurrence of LBW and can make better decisions about their health and their infants. ${ }^{16}$ In the future, it is expected that it will not occur too late (in making decisions to seek emergency for medical efforts, in arriving at health facilities, and in getting adequate medical help).

The rationale for the relationship between maternal educational level and LBW is indirectly related to the mother's low socio-economic level, which may have lower weight gain during pregnancy, late initiation of prenatal care, and less consultation than recommended. Prenatal care and the number of consultations are also associated indirectly with maternal educational level. Mothers with higher levels of education are twice as likely to do more than six consultations during the prenatal period and to be the first to do. ${ }^{17}$ Mothers with a higher level of education have a greater sense of responsibility in taking care of themselves, have more knowledge about what they should do, have higher socioeconomic status, and better judgment when making decisions about their health. Several studies conducted in various countries have shown that education is the strongest socioeconomic predictor of health status and the most important determinant of birth weight in a population. ${ }^{18}$

\section{Conclusion}

Based on the obtained results, it can be concluded that there was an influence of maternal educational status during pregnancy on the incidence of infants with LBW in Dr. M. Soewandhie General Hospital Surabaya.

\section{CONFLICT OF INTEREST}

The author stated there is no conflict of interest in this study.

\section{REFERENCES}

1. Indonesia KKR. Rencana Strategis Kementerian Kesehatan Tahun 2015 - 2019. Jakarta: Kementerian Kesehatan Republik Indonesia, 2015.

2. Nasional BPP. Rencana Pembangunan Jangka Menengah Nasional (RPJMN) 2015-2019. Jakarta: Badan Perencanaan Pembangunan Nasional, 2014.

3. Kasim MS, Yunanto A, Dewi R, Sarosa GI and Usman

A. Buku Ajar Neonatologi. Edisi : 1; Cetakan : 1 ed. Jakarta: Badan Penerbit IDAI, 2008.

4. Kesehatan BPdP. Riset Kesehatan Dasar. Jakarta: Kementerian Kesehatan Republik Indonesia, 2013.

5. Timur DKPJ. Profil Kesehatan Provinsi Jawa Timur Tahun 2014. Surabaya: Dinas Kesehatan Provinsi Jawa Timur, 2015.

6. Surabaya DKK. Profil Kesehatan Tahun 2015. Surabaya: Dinas Kesehatan Kota Surabaya, 2015.

7. Almatsier S. Gizi Seimbang dalam Daur Kehidupan. Gramedia, 2011.

8. Mercier CE, Dunn MS, Ferrelli KR, Howard DB and Soll RF. Neurodevelopmental Outcome of Extremely Low Birth Weight Infants from the Vermont Oxford network: 19982003. Neonatology. 2010; 97: 329-38.

9. Alya D. Faktor-Faktor yang Berhubungan dengan Bayi Berat Lahir Rendah (BBLR) di Rumah Sakit Ibu dan Anak Banda Aceh Tahun 2013. Banda Aceh: STIKES Ubudiyah 2014

10. Sulistiani K. Faktor Risiko Kejadian Bayi Berat Lahir Rendah (BBLR) di Wilayah Kerja Puskesmas Kota Tangerang Selatan tahun 2012-2014.

11. Mahayana SAS, Chundrayetti E and Yulistini Y. Faktor Risiko yang Berpengaruh terhadap Kejadian Berat Badan Lahir Rendah di RSUP Dr. M. Djamil Padang. Jurnal Kesehatan Andalas. 2015; 4

12. Suwarni $Y$, Noor MS and Rahayu A. Hubungan antara Paritas, LILA, Kadar Hb dan Usia Ibu Hamil dengan Berat Lahir Bayi. Jurnal Publikasi Kesehatan Masyarakat Indonesia. 1.

13. Kumalasari I, Tjekyan RS and Zulkarnain M. Faktor Resiko dan Angka Kejadian Berat Badan Lahir Rendah (BBLT) di RSUP Dr. Mohammad Hoesin Palembang Tahun 2014. Jurnal IImu Kesehatan Masyarakat. 2018; 9.

14. Ekaningrum AY. Hubungan Komplikasi Kehamilan dengan Kejadian BBLR di Indonesia Tahun 2012. 2018.

15. Silva LM, Jansen PW, Steegers EA, et al. Mother's Educational Level and Fetal Growth: The Genesis of Health Inequalities. International Journal of Epidemiology. 2010; 39: 1250-61.

16. Silvestrin S, da Silva CH, Hirakata VN, Goldani AAS, Silveira PP and Goldani MZ. Maternal Education Level and Low Birth Weight: A Meta-Analysis. Jornal de Pediatria. 2013; 89: 339-45.

17. Haidar FH, Oliveira UF and Nascimento LFC Escolaridade materna: correlação com os indicadores obstétricos. Cadernos de Saúde Pública. 2001; 17: 10259

18. Maddah M, Karandish M, Mohammadpour-Ahranjani B, Neyestani TR, Vafa R and Rashidi A. Social Factors and Pregnancy Weight Gain in Relation to Infant Birth Weight: A Study in Public Health Centers in Rasht, Iran. European Journal of Clinical Nutrition. 2005; 59: 1208-12. 